\title{
Статистичне моделювання фінансової безпеки України
}

Стаття присвячена узагальненню теоретичних основ формування фінансової безпеки України, статистичному аналізу основних зовнішніх та внутрішніх показників впливу на складові безпеки краӥни. Проаналізовано динаміку інтегральних показників банківської, бюджетної, валютної, грошово-кредитної безпеки та безпеки небанківського фінансового ринку. Економічну діагностику проведено та порівняно на основі двох методик: рекомендації Міністерства економічного розвитку та торгівлі й Національного інституту проблем міжнародної безпеки України. Розроблено економіко-статистичну модель фінансової безпеки України в залежності від факторів монетизачії економіки, рівня дефіциту бюджету та інфляиії.

Ключові слова: фінансова безпека, інтегральний показник, статистична модель, інфляція, грошово-кредитна система, банківська безпека.

Постановка проблеми. Становлення України як незалежного суб'єкта міжнародної економічної діяльності в умовах глобалізації дедалі більшою мірою обумовлює іiі залежність від зовнішніх економічних факторів, які притаманні усім елементам економічної взаємозалежності країн. Внаслідок цього все більшого значення набувають такі поняття як національна, економічна та фінансова безпека держави.

Концепція фінансової безпеки спрямована на виявлення та усунення проблем і загроз, що заважають забезпеченню цінової та фінансової стабільності і, як наслідок, гальмують проведення структурних реформ у національній економіці. Створення дієвої системи фінансової безпеки передбачає чітке визначення джерел потенційних загроз в тій чи іншій сфері, а також наявних і необхідних ресурсів для їх нейтралізації, що обумовлює актуальність досліджень, пов'язаних з моделюванням фінансової безпеки України.

Аналіз досліджень і публікацій. Проблематикою фінансової безпеки займалися такі вчені як В. Геєць, Е. Дмитренко, М. Срмошенко, В. Мунтіян та інші. О. Барановським обгрунтовано врівень захищеності фінансових інтересів на всіх рівнях фінансових відносин [1], 3. Варналієм охарактеризовано особливості соціальноекономічного розвитку країни в умовах обслуговування фінансових зобов'язань [2]. Однак питання статистичного моделювання залишаються на сьогодні недостатньо опрацьованими.

Метою статті є визначення проблем забезпечення фінансової безпеки України на основі статистичного моделювання та встановлення шляхів ії поліпшення.

Результати дослідження. Забезпечення національних інтересів й економічної безпеки $є$ найважливішими функціями держави, реалізація яких спрямована на посилення їі позицій в міжнародному співтоваристві.

На фінансову безпеку впливає дія внутрішніх і зовнішніх факторів. Наявність внутрішніх факторів пов'язують із організаційно-правовою, адміністративною та інституційною незавершеністю реформування фінансово-кредитної сфери, політичною нестабільністю. Зовнішніми вважаються такі фактори як невизначеність держави в сучасному геополітичному просторі, їі непричетність до інтеграційних процесів; обмежений доступ до закордонних фінансових ринків, безконтрольне накопичення зовнішньої заборгованості. Факторами, що формують загрози фінансовій безпеці держави, також є динаміка сальдо торгового та платіжного балансу і значна

(C) О. К. Слісєєва, 2018 
залежність від експортно-імпортної діяльності; втручання міжнародних фінансових організацій у внутрішні справи держави; вплив світових фінансових криз на фінансову систему держави.

Фінансова безпека держави характеризується певним набором показників, кожен із яких має порогове значення, яке встановлюється в залежності від рівня економічного розвитку. Міністерством економіки України розроблено методику розрахунку рівня економічної безпеки, в якій виокремлено групу індикаторів фінансової безпеки: бюджетна безпека, безпека грошового ринку та інфляційних процесів, валютна безпека, валові міжнародні резерви, безпека страхового ринку, безпека фондового ринку, банківська безпека [9]. Індикатори фінансової безпеки сигналізують про виникнення проблемних ситуацій та диспропорцій розвитку [3]. Фундаментальність та масштабність проблеми, різноплановість самого змісту фінансової безпеки та ії забезпечення вимагають формування інформаційно-аналітичної бази для моніторингу показників фінансової безпеки [1, с. 5-7; 12].

Ступінь впливу загроз можна визначити на основі моніторингу системи показників та порівняння їх із пороговими.

Для статистичного моделювання фінансової безпеки України використано методичні рекомендації Міністерства економічного розвитку та торгівлі [7; 8]. На рис. 1 подано динаміку інтегрального показника банківської безпеки України.

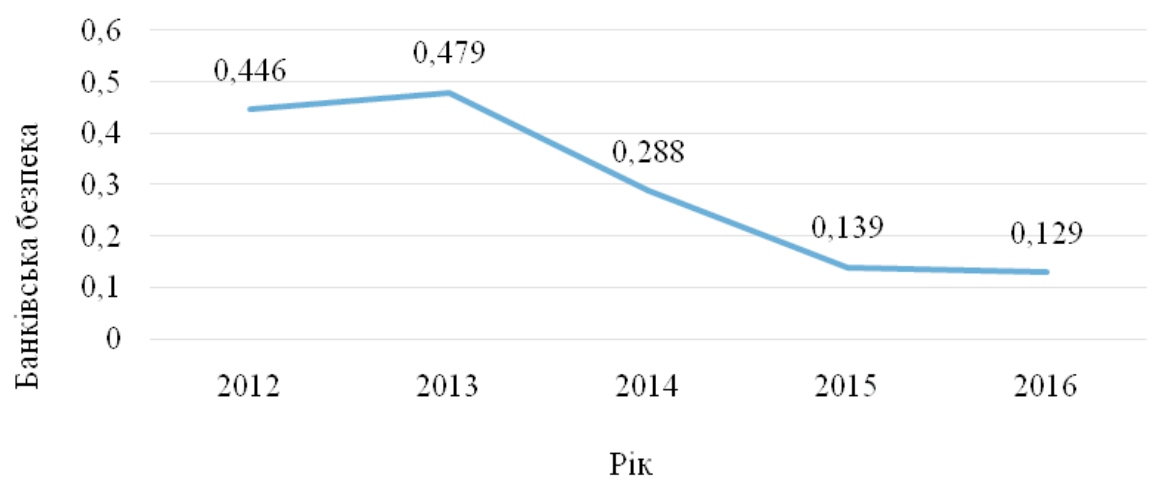

Рис. 1. Інтегральний показник банківської безпеки України Джерело: побудовано автором за даними $[7 ; 8]$

Протягом 2012-2013 рр. значення інтегрального показника мало тенденцію до зростання, тобто спостерігалося підвищення рівня безпеки банківської системи 3 критичного у 2012 р. до незадовільного у 2013 р. Така тенденція була зумовлена зменшенням частки простроченої заборгованості за кредитами на 20\% у 2014 р. у порівняні з 2013 р., банківських кредитів та депозитів в іноземній валюті - на 19\%, частки іноземного капіталу у статутному капіталі банків - на 7,9 відсоткових пунктів (в. п.), зростанням частки п’яти найбільших банків у сукупних активах банківської системи на 9,35\%. Однак у 2014 р. значення показника зазнало різкого зменшення на $40 \%$, а у 2015 р. порівняно з попереднім роком - на 52\%. У 2016 р. показник банківської безпеки становив 0,129 , що є найменшим за аналізований період. Причинами такого різкого зниження є зростання частки простроченої заборгованості за кредитами на 64\%, обсягу кредитів та депозитів в іноземній валюті на 10,47\%, зниження рентабельності банківських активів на $34 \%$.

Проаналізуємо безпеку небанківського фінансового ринку (рис. 2).

Найвище значення інтегрального показника безпеки небанківського фінансового ринку спостерігалось у 2012 р. - 0,3948 ( небезпечний рівень), а найнижче у 2016 р. 0,213 (критичний рівень). Така ситуація виникла внаслідок зниження рівня капіталізації лістингових компаній щодо ВВП на $84 \%$, а також зростання частки страхових премій трьох найбільших страхових компаній у ВВП на 4,8 в. п. 


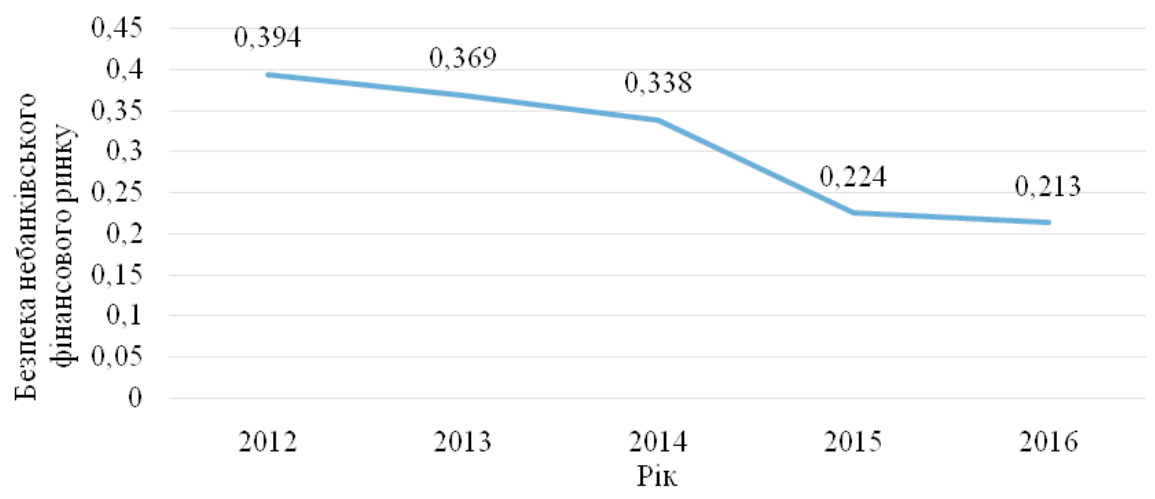

Рис. 2. Інтегральний показник безпеки небанківського фінансового ринку України

Джерело: побудовано автором за даними [7; 8]

Динаміку інтегрального показника боргової безпеки України наведено на рис. 3.

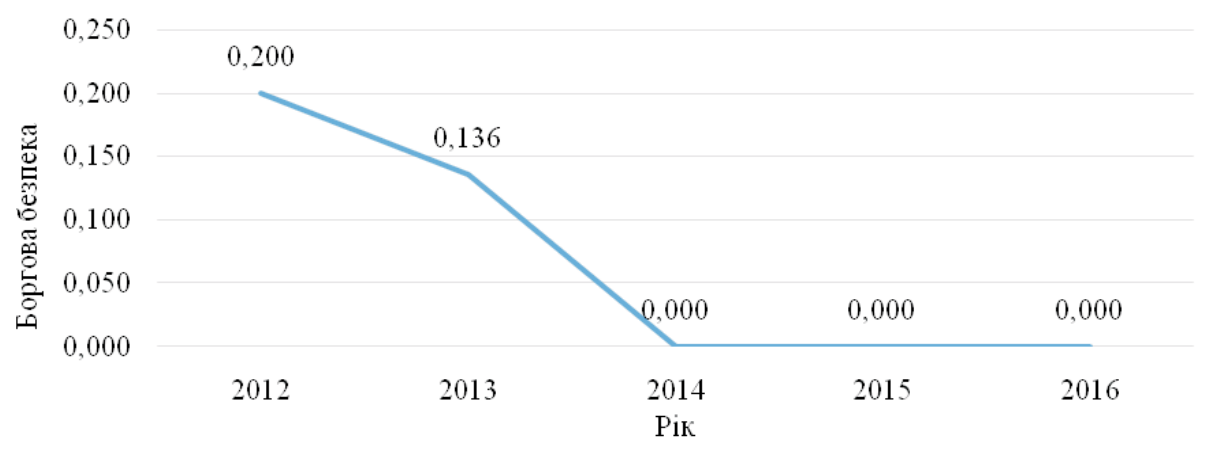

Рис. 3. Динаміка показника боргової безпеки України

Джерело: побудовано автором за даними [7; 8]

Розглядаючи інтегральний показник боргової безпеки, варто наголосити на тому, що його значення порівняно з іншими сферами фінансової безпеки були найнижчими, а в період 2014-2016 рр. взагалі дорівнювали нулю. Це зумовлено зростанням обсягу державного та гарантованого державою боргу щодо ВВП на 147\% у 2016 р. проти 2012 р., валового зовнішнього боргу - на 93\%, зменшенням обсягу офіційних міжнародних резервів щодо розміру зовнішнього боргу на $61 \%$.

Динаміку інтегрального показника бюджетної безпеки України подано на рис. 4.

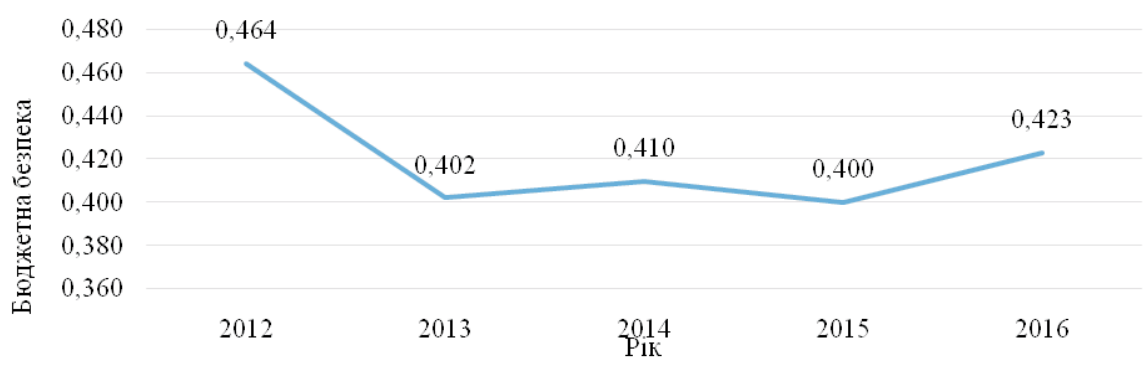

Рис. 4. Динаміка інтегрального показника бюджетної безпеки України Джерело: побудовано автором за даними [7; 8]

Бюджетна безпека протягом досліджуваного періоду перебувала на “небезпечному рівні” з урахуванням незначних коливань. Так, у 2012 р. значення інтегрального по- 
казника бюджетної безпеки було зафіксовано на максимальному рівні 0,464, однак до кінця 2015 р. він знизився на 18\%: за рахунок зростання дефіциту державного бюджету щодо ВВП - на 30\%, рівня перерозподілу ВВП через зведений бюджет - на 1,67 в. п., збільшення обсягу сукупних платежів з обслуговування та погашення державного боргу щодо доходів бюджету - на 72,64 в. п. Але у 2016 р. цей показник збільшився на 5,75\%.

Проаналізуємо динаміку інтегрального показника валютної безпеки (рис. 5).

В період 2012-2013 рр. стан валютної безпеки характеризувався незадовільним рівнем, що зумовлено більш стабільним курсом гривні до іноземних валют, зменшенням частки кредитів в іноземній валюті на 16\% тощо. Однак починаючи з 2014 р. рівень безпеки знизився до критичного.

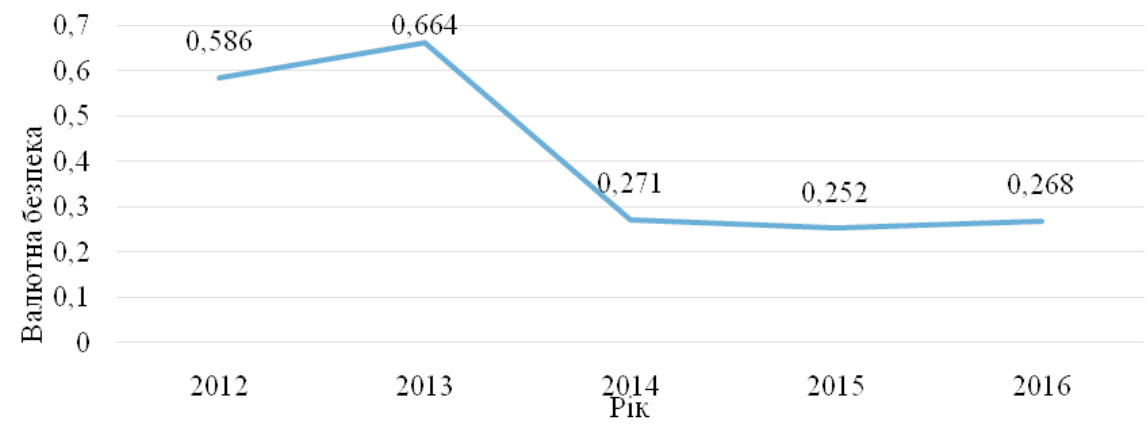

Рис. 5. Динаміка інтегрального показника валютної безпеки України

Джерело: побудовано автором за даними [7; 8]

Причиною такого стану стала девальвація національної грошової одиниці. Так, індекс зміни офіційного курсу гривні до долара США з 100,02 у 2013 р. зріс до 183,52 у 2015 р., тобто його приріст становив 83,48\%, імпорт валових міжнародних резервів України знизився на $31 \%$, кредити в іноземній валюті зросли на 23 в. п., рівень доларизації - на 18,5\%.

Динаміку інтегрального показника грошово-кредитної безпеки наведено на рис. 6.

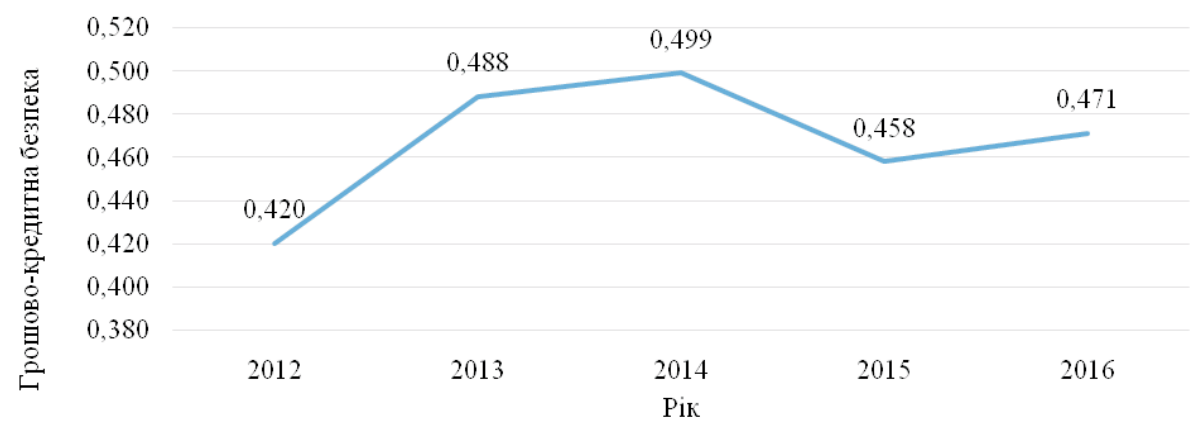

\section{Рис. 6. Динаміка інтегрального показника грошово-кредитної безпеки України}

Джерело: побудовано автором за даними [7; 8]

Грошово-кредитна безпека, як і бюджетна безпека, впродовж досліджуваного періоду перебувала на “небезпечному” рівні. Цьому сприяло збільшення питомої ваги готівки поза банками в загальному обсязі грошової маси на 8,72\%, збільшення різниці між відсотковими ставками за кредитами та депозитами на 1,90 в. п., зниження рівня середньозваженої облікової ставки за кредитами, наданими депозитними корпораціями (крім НБУ) в національній валюті, відносно індексу споживчих цін, скорочення частки споживчих кредитів, наданих домогосподарствам.

На основі сформованих інтегральних показників підсистем фінансової безпеки розраховано загальний індикатор фінансової безпеки.

У період 2012-2013 рр. рівень фінансової безпеки оцінювався як “небезпечний”. У 2014 р. значення інтегрального показника фінансової безпеки становило 0,3041, що 
на 0,1209 нижче, ніж у 2013 р. Станом на 2015 р. рівень фінансової безпеки України був критичним і становив 0,2517 , що на 0,0524 нижче попереднього року. Зменшення інтегрального показника фінансової безпеки у 2016 р. на 0,087 в. п. свідчило про неспроможність фінансової системи протистояти негативним внутрішнім та зовнішнім факторам, а відтак про послаблення фінансової безпеки всієї країни.

Крім того, для порівняння отриманих результатів проведено розрахунок рівня фінансової безпеки за методикою Національного інституту проблем міжнародної безпеки України (таблиця).

Таблиия

Динаміка показників фінансової безпеки за методикою

Національного інституту проблем міжнародної безпеки України

\begin{tabular}{|c|c|c|c|c|c|c|c|c|}
\hline \multirow[b]{2}{*}{ Показник } & \multirow[b]{2}{*}{$\begin{array}{c}\text { Порогове } \\
\text { значення } \\
\text { показника }\end{array}$} & \multicolumn{5}{|c|}{ Роки } & \multicolumn{2}{|c|}{ Абсол. відх. (+/-) } \\
\hline & & 2012 & 2013 & 2014 & 2015 & 2016 & $\begin{array}{l}2014 \mathrm{p} . \\
\text { від } \\
2012 \mathrm{p} .\end{array}$ & $\begin{array}{l}2016 \mathrm{p} . \\
\text { від } \\
2014 \mathrm{p} .\end{array}$ \\
\hline Рівень інфляції, \% & $5 \%$ & $-0,2$ & 0,5 & 24,9 & 43,3 & 12,4 & 25,1 & $-12,5$ \\
\hline $\begin{array}{l}\text { Обсяг внутрішньо- } \\
\text { го боргу, \% ВВП }\end{array}$ & $\begin{array}{c}\text { менше } 30 \% \\
\text { ВВП }\end{array}$ & 35,33 & 38,82 & 70,26 & 79,4 & 71,43 & 34,93 & 1,17 \\
\hline $\begin{array}{l}\text { Обсяг зовнішнього } \\
\text { боргу, \% ВВП }\end{array}$ & $\begin{array}{c}\text { менше 20\% } \\
\text { ВВП }\end{array}$ & 76,6 & 78,3 & 96,05 & 148,99 & 131,3 & 19,45 & 35,25 \\
\hline $\begin{array}{l}\text { Дефіцит держав- } \\
\text { ного бюджету, } \\
\text { \% ВВП }\end{array}$ & $1 \%$ ВВП & 3,66 & 4,3 & 4,98 & 2,28 & 2,94 & 1,32 & $-2,04$ \\
\hline $\begin{array}{l}\text { Рівень монетизації, } \\
\text { \% ВВП }\end{array}$ & 30\% ВВП & 54,88 & 62,48 & 61,07 & 50,29 & 51,08 & 6,19 & $-9,99$ \\
\hline $\begin{array}{l}\text { Вартість банків- } \\
\text { ських кредитів, } \\
\text { річних, \% }\end{array}$ & $\begin{array}{l}\text { Не більше } \\
10 \% \text { річних }\end{array}$ & 26,6 & 25,3 & 26,1 & 29,5 & 18,3 & $-0,5$ & $-7,8$ \\
\hline $\begin{array}{l}\text { Міжнародні резер- } \\
\text { ви (без золотих), } \\
\text { млрд дол. США }\end{array}$ & $\begin{array}{c}\text { До } \\
5 \text { млрд дол. } \\
\text { США }\end{array}$ & 22,66 & 18,78 & 6,62 & 12,37 & 14,59 & $-16,04$ & 7,97 \\
\hline
\end{tabular}

Джерело: побудовано автором за даними [7; 8]

Значення усіх показників протягом 2012-2016 рр. суттєво перевищують порогові значення. Так, рівень інфляції був найвищим у 2015 р. (майже у десять разів перевищив встановлене порогове значення). В рейтингу країн за рівнем інфляції, складеному Центральним розвідувальним управлінням США, Україна станом на 2015 р. посіла передостаннє 224 місце, а останнє, 225 місце, - Південний Судан (52,80\%) [6].

Особливу увагу варто приділити показнику відношення обсягу зовнішнього боргу до ВВП, адже в 2015 р. його він становив 148,99\%, тоді як його порогове значення не має перевищувати $20 \%$.

Проведені розрахунки показали, що дефіцит державного бюджету до 2014 р. мав тенденцію до зростання і майже у п'ять разів перевищив порогове значення. Проте у 2015 р. він скоротився у 2,5 раза і становив $2,28 \%$ ВВП. Однак навіть таке суттєве зниження не сприяло оптимізації розміру дефіциту державного бюджету порівняно з ВВП.

Найвищий рівень монетизації протягом досліджуваного періоду зареєстровано у 2013 р. на рівні 62,48\%, а найменший - у 2015 р. (50,29\%). Тобто в досліджуваному періоді цей показник завжди перевищував власне порогове значення, що призвело до зменшення швидкості обертання грошей у країні. Варто також зазначити, що вартість банківських кредитів протягом 2012-2016 рр. не відповідала оптимальному значенню. Так, у 2015 р. значення показника монетизації становило 29,50\%, що, відповідно, на 3,4 та 19,5 в. п. більше, ніж у 2014 р., та порогового значення.

Найбільший обсяг міжнародних резервів України спостерігався у 2012 р. у розмірі 22,66 млрд дол., а найменший - у 2014 р. (6,62 млрд дол.), що є негативним явищем, адже максимально допустимий рівень їх розміру не має перевищувати 5 млрд дол. 
Найбільшими загрозами при цьому є збільшення зовнішнього боргу, зростання рівня доларизації, девальвація гривні, високі темпи інфляційних процесів.

Одним із важливих моментів статистичного аналізу є виявлення взаємозв'язків між досліджуваними показниками. Для використовуються економіко-статистичні моделі.

Для побудови моделі використано показники, запропоновані Національним інститутом проблем міжнародної безпеки України, а саме рівень монетизації економіки, рівень дефіциту бюджету, інфляція.

Метою побудови моделі є вплив варіації монетизації економіки, рівня дефіциту бюджету, інфляції на рівень фінансової безпеки України. Статистична модель впливу має вигляд: $y=1,4971 x_{1}-5,0784 x_{2}-0,3105 x_{3}+3,228+\mathrm{e}$,

де у - рівень фінансової безпеки, $\mathrm{x}_{1}$ - рівень монетизації економіки, $\mathrm{x}_{2}-$ рівень дефіциту бюджету, х - - інфляція.

Значимість моделі підтверджується критерієм Фішера. Значення $\mathrm{R}^{2}=0,80$ показує, що варіацію залежної змінної на 80\% можна пояснити варіацією включених у модель змінних.

Значимість моделі перевірена за допомогою критерію Фішера $(\mathrm{F}=0,068>0,05)$. Для перевірки статистичної значущості оцінок параметрів використаємо t-статистику Стьюдента, згідно з цим критерієм усі оцінки є значущими.

Величина скоригованого значення коефіцієнта детермінації залишилася досить великою, що свідчить про правильно обрану специфікацію моделі. Перевірка якості побудованої моделі здійснюється за допомогою дисперсійного аналізу. Прогнозні варіанти зміни рівня фінансової безпеки в Україні на 2017-2018 роки показано на рис. 7.

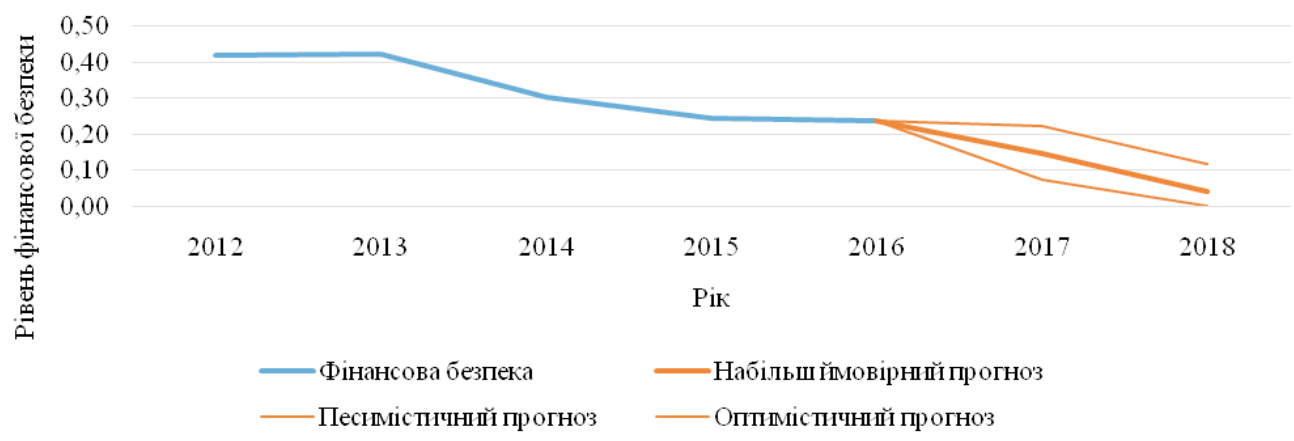

\section{Рис. 7. Прогноз зміни рівня фінансової безпеки на 2017-2018 рр.}

Відповідно до моделі, прогнозований рівень фінансової безпеки складатиме за найбільш імовірним прогнозом 0,15 у 2017 р. і -0,05 у 2018 р. Така тенденція свідчить про подальше зменшення рівня фінансової безпеки в Україні.

Висновки. Результати проведеного статистичного аналізу та моделювання показують, що зміцнення фінансової безпеки в Україні перш за все потрібно розпочати з безпеки банківського сектору. Для цього необхідно: активізувати роботу в напрямку зміцнення власної капітальної бази банками, розробити заходи щодо запобігання відтоку депозитів фізичних осіб, відновити довіру населення щодо розміщення коштів на довгостроковій основі, зменшити ставки за кредитними ресурсами, наближаючи їх до рівня європейських країн, зменшити присутність іноземного капіталу в банківській системі України.

Наступним кроком $є$ зміцнення бюджетної безпеки. В Україні необхідно удосконалити інструменти залучення інвестицій із заощаджень приватного сектору та доходів населення, розробити модель оптимального поєднання внутрішніх та зовнішніх джерел фінансування бюджетного дефіциту.

Для зміцнення боргової безпеки необхідним є зменшення від’ємного сальдо торговельного балансу України; збільшення рівня золотовалютних резервів; використання позикових коштів міжнародних організацій на стимулювання економічного розвитку країни. 
Для покращення фінансової безпеки країни необхідним є збільшення рівня валютної та монетарної безпеки; зменшення питомої ваги готівкових коштів у загальному обсязі грошової маси, що сприятиме зменшенню рівня тонізації економіки; збалансування грошового й товарного ринків, тобто зниження рівня інфляції.

Реалізація запропонованого комплексу заходів щодо фінансової безпеки, дозволить підвищити іiі рівень за умови забезпечення підтримки на законодавчому і виконавчому рівнях.

\section{Список використаних джерел}

1. Барановський О. І. Фінансова безпека в Україні (методологія оцінки та механізми забезпечення): моногр. К.: КНТЕУ, 2004. 759 с.

2. Варналій 3. С. Економічна безпека : навч. посіб. К.: Знання, 2009. 647 с.

3. Карпінський Б. А. Збалансованість фінансової системи: методологія, оцінка, порівняння: моногр. Львів: Логос, 2005. 496 с.

4. Методика розрахунку рівня економічної безпеки України / Офіційний сайт Мiністерства економіки України [Електронний ресурc]. URL: http://www.me.gov.ua/ control/uk/publish/article?art id $=97980 \&$ cat_id $=38738$.

5. Михасюк I., Мельник А., Крупка М., Залога 3. Державне регулювання економіки. Львів: Українські технології, 1999. 639 с.

6. Опарін В. Фінансова система України (теоретико-методологічні аспекти): моногр. К.: КНЕУ, 2006. 240 c.

7. Офіційний сайт Державної служби статистики [Електронний ресурс]. URL: http:// www.ukrstat.gov.ua

8. Офіційний сайт Національного банку України [Електронний ресурс]. URL: http:// www.bank.gov.ua

9. Про затвердження Методичних рекомендацій щодо розрахунку рівня економічної безпеки України: Наказ Міністерства економічного розвитку і торгівлі України № 1277 від 29.10.2013 р. [Електронний ресурс]. URL: http://search.ligazakon. ua/1_doc2.nsf/ link1/ME131588.htm.

10. Про Концепцію (основи державної політики) національної безпеки України: Постанова ВРУ № 3/97-BР від 16.01.1997 [Електронний ресурc]. URL: http://ukraine. uapravo.net/data/base55/ukr55587.htm.

\section{References}

1. Baranovskyi O. I. (2004). Finansova bezpeka v Ukraini (metodolohiia otsinky ta mekhanizmy zabezpechennia) [The financial security in Ukraine (a methodology for assessment and mechanisms]. Kyiv: KNTEU [in Ukrainian].

2. Varnalii Z. S. (2009). Ekonomichna bezpeka [The economic security]. Kyiv: Znannia [in Ukrainian].

3. Karpinskyi B. A. (2005). Zbalansovanist finansovoi systemy: metodolohiia, otsinka, porivniannia [The balance of financial system: methodology, assessment, comparisons]. Lviv: Lohos [in Ukrainian].

4. Metodyka rozrakhunku rivnia ekonomichnoi bezpeky Ukrainy. Ofitsiinyi sait Ministerstva ekonomiky Ukrainy [The method for computation of the economic security level in Ukraine. The official web-site of the Ukrainian Ministry of Economy]. Retrieved from http://www.me.gov.ua/control/uk/publish/article?art_id=97980\& cat_id=38738. [in Ukrainian].

5. Mykhasiuk I., Melnyk A., Krupka M. et al. (1999). Derzhavne rehuliuvannia ekonomiky [Government regulation of the economy]. Lviv: Ukrainski tekhnolohii [in Ukrainian].

6. Oparin V. (2006). Finansova systema Ukrainy (teoretyko-metodolohichni aspekty) [The financial system of Ukraine (theoretical and methodological aspects)]. Kyiv: KNEU [in Ukrainian].

7. Ofitsiinyi sait Derzhavnoi sluzhby statystyky [The official web-site of the State Statistics Service of Ukraine]. Retrieved from http://www.ukrstat.gov.ua [in Ukrainian].

8. Ofitsiinyi sait Natsionalnoho banku Ukrainy [The official web-site of the National Bank of Ukraine]. Retrieved from http://www.bank.gov.ua [in Ukrainian]. 
9. Pro zatverdzhennia Metodychnykh rekomendatsii shchodo rozrakhunku rivnia ekonomichnoi bezpeky Ukrainy: Nakaz Ministerstva ekonomichnoho rozvytku i torhivli Ukrainy No 1277 vid 29.10.2013 r. [On the approval of methodical recommendations on computation of the economic security level in Ukraine: the Order of the Ukrainian Ministry for Economic Development and Trade No 1277 from 29.10.2013]. Retrieved from http://search.ligazakon.ua/1_doc2.nsf/ link1/ME131588.htm. [in Ukrainian].

10. Pro Kontseptsiiu (osnovy derzhavnoi polityky) natsionalnoi bezpeky Ukrainy: Postanova VRU No 3/97-VR vid 16.01.1997 [On the Guidelines (political principles) of the national security in Ukraine: the Decree of the Verkhovna Rada of Ukraine No 3/97-VR from 16.01.1997]. Retrieved from http://ukraine.uapravo.net/data/base55/ukr55587.htm.

О. К. ЕЛИСЕЕВА доктор экономических наук, профессор, заведуюший кафедрой статистики, учета и экономической информатики, Днепровский национальный университет имени Олеся Гончара

\section{Статистическое моделирование финансовой безопасности Украины}

Статья посвящена обобщению теоретических основ формирования финансовой безопасности Украины, статистическому анализу основных внешних и внутренних показателей воздействия на составляющие безопасности страны. Проанализирована динамика интегральных показателей банковской, бюджетной, валютной, денежно-кредитной безопасности и безопасности небанковского финансового рынка. Проведена диагностика финансовой безопасности Украины на основе двух методик: рекомендации Министерства экономического развития и торговли и Национального института проблем международной безопасности Украины. Разработана экономико-статистическая модель финансовой безопасности Украиньь в зависимости от факторов монетизации экономики, уровня дефицита бюджета и инфляции.

Ключевые слова: финансовая безопасность, интегральный показатель, статистическая модель, инфляция, денежно-кредитная система, банковская безопасHость.

O. K. YELISYEYEVA, Dsc (Economics), Professor, Head of the Department for Statistics, Accounting and Economic Informatics, Oles Honchar Dnipro National University

\section{Statistical Modeling of the Financial Security in Ukraine}

A financial security system will be effective once the sources of potential threats and the resources available or required for their elimination are clearly defined and assessed, which raises the importance of studies focused on modeling of the financial security in Ukraine. The problems of financial security in Ukraine are addressed in the article through the prism of statistical modeling and finding ways for security enhancement.

The internal and external factors affecting the financial security of a country are highlighted. The modeling of the financial security in Ukraine is conducted by the methodic recommendations of the Ukrainian Ministry for Economic Development and Trade and the National Institute for International Security Problems of Ukraine. The integral indicators of bank security, security of non-banking financial sector, debt security, budget security, currency security, monetary security (all for Ukraine) over 2012-2016 are analyzed. An econometric model of the financial security in Ukraine is constructed using the factors of economy's monetization, budget deficit and inflation. The expected level of financial security of Ukraine in 2017-2018 is estimated. According to the model, the most likely level will 
make 0.15 in 2017 and -0.05 in 2018, showing the decreasing level of financial security in Ukraine. Recommendations on the financial security enhancement are given.

Keywords: financial security, integral indicator, statistical model, inflation, monetary system, bank security.

\section{Посилання на статтю:}

Єлісєєва О. К. Статистичне моделювання фінансової безпеки України // Науковий вісник Національної академії статистики, обліку та аудиту: зб. наук. пр. 2018. №1-2. C. 10-18 